\title{
Source apportionment of fine organic aerosol in Mexico City during the MILAGRO experiment 2006
}

\author{
E. A. Stone ${ }^{1}$, D. C. Snyder ${ }^{1}$, R. J. Sheesley ${ }^{1}$, A. P. Sullivan ${ }^{2}$, R. J. Weber ${ }^{2}$, and J. J. Schauer ${ }^{2}$ \\ ${ }^{1}$ Environmental Chemistry and Technology, University of Wisconsin-Madison, Madison, WI, USA, 53706 \\ ${ }^{2}$ School of Earth and Atmospheric Sciences, Georgia Institute of Technology, Atlanta, GA, USA, 30332
}

Received: 19 June 2007 - Published in Atmos. Chem. Phys. Discuss.: 4 July 2007

Revised: 1 October 2007 - Accepted: 23 October 2007 - Published: 4 March 2008

\begin{abstract}
Organic carbon (OC) comprises a large fraction of fine particulate matter $\left(\mathrm{PM}_{2.5}\right)$ in Mexico City. Daily and select 12-h $\mathrm{PM}_{2.5}$ samples were collected in urban and peripheral sites in Mexico City from 17-30 March 2006. Samples were analyzed for OC and elemental carbon (EC) using thermal-optical filter-based methods. Real-time watersoluble organic carbon (WSOC) was collected at the peripheral site. Organic compounds, particularly molecular markers, were quantified by soxhlet extraction with methanol and dichloromethane, derivitization, and gas chromatography with mass spectrometric detection (GCMS). A chemical mass balance model (CMB) based on molecular marker species was used to determine the relative contribution of major sources to ambient OC. Motor vehicles, including diesel and gasoline, consistently accounted for $49 \%$ of OC in the urban area and $32 \%$ on the periphery. The daily contribution of biomass burning to OC was highly variable, and ranged from $5-26 \%$ at the urban site and $7-39 \%$ at the peripheral site. The remaining OC unapportioned to primary sources showed a strong correlation with WSOC and was considered to be secondary in nature. Comparison of temporally resolved OC showed that contributions from primary aerosol sources during daylight hours were not significantly different from nighttime. This study provides quantitative understanding of the important sources of OC during the MILAGRO 2006 field campaign.
\end{abstract}

\section{Introduction}

The Megacity Impacts on Regional and Global Environment (MIRAGE) study of the atmosphere in Mexico City, as part of the Megacity Initiative: Local and Global Research Observations (MILAGRO), targets the chemical characterization

Correspondence to: J. J. Schauer

(jjschauer@wisc.edu) and transformation of atmospheric pollutants generated in and transported from the urban area (NCAR/EOL, 2006). The air pollution generated in megacities poses a threat to human health and the environment; Mexico City has experienced extreme urbanization in the last century which has caused many environmental problems, including severe air pollution (Molina and Molina, 2004). This capitol city and its nearly 20 million inhabitants reside in an elevated basin, $2240 \mathrm{~m}$ above sea level nearly surrounded by mountain ranges. Airborne PM frequently exceeds maximum concentrations allowed by air quality standards (Molina and Molina, 2004) and high levels of PM have been associated with negative health impacts (Dockery et al., 1992; Saldiva et al., 1995; Schwartz and Marcus, 1990). Aerosols may play an important role in the radiative balance of the earth through the direct absorption or reflection of incident solar radiation or indirectly as cloud condensation nuclei (CCN) (Sun and Ariya, 2006). The climate forcing of aerosols generated in the Mexico City metropolitan area may affect the surrounding region.

Mexico City has been the location of several air pollution field studies in the last half-century. The majority of these studies have focused on the elemental composition of PM (Raga et al., 2001); approximately half of the total aerosol mass in Mexico City was observed to be organic matter (Chow et al., 2002; Edgerton et al., 1999; Salcedo et al., 2006). $\mathrm{PM}_{2.5}$ analyzed at six locations in urban Mexico City from 2-19 March 2003 had an average organic carbon (OC) concentration of $9.98 \mu \mathrm{g} \mathrm{m}^{-3}$ and an elemental carbon (EC) concentration of $5.82 \mu \mathrm{g} \mathrm{m}^{-3}$ (Chow et al., 2002). These levels are comparable to those observed in downtown Los Angeles, California (LA) (Schauer et al., 1996) and in three Chinese megacities, Beijing, Shanghai, and Guangzhou, during the summertime (Feng et al., 2006).

The primary sources contributing to fine particle $\mathrm{OC}$ in Mexico City have not previously been studied and source reconciliation has been limited. One multivariate analysis of

Published by Copernicus Publications on behalf of the European Geosciences Union. 
$\mathrm{PM}_{2.5}$ mass based on inorganic species found major primary sources to be industry, wind-blown soil, and biomass burning (Johnson et al., 2006). There is reason to believe, however, that additional sources to $\mathrm{PM}_{2.5}$ are important, although they may not have inorganic chemical signatures. Emissions inventories for gas-phase pollutants in Mexico City have pointed towards motor vehicles as their most substantial source (Schifter et al., 2004) which makes it likely that motor vehicles are also a major source of ambient PM. Several studies of fine particle OC have identified diurnal trends in ambient concentration that correspond temporally to traffic patterns which support this hypothesis (Chow et al., 2002; Marr et al., 2006; Salcedo et al., 2006). To comprehensively understand the sources of $\mathrm{OC}$ source apportionment should be based on specific organic compounds.

The goal of the research presented in this paper was to determine the important sources of organic aerosol in Mexico City and quantitatively assess their mass contributions. This was accomplished through quantification of OC, EC, watersoluble organic carbon (WSOC), and solvent-extractable organic molecular markers in $\mathrm{PM}_{2.5}$ and chemical mass balance (CMB) modeling. This study assessed the temporal variability of organic species and important aerosol sources. The geographic variability of OC was evaluated by comparing samples collected at an urban site in Mexico City and a peripheral site, located on the outskirts of the metropolitan area. This study aims to provide a concrete understanding of the primary sources of OC in Mexico City to compliment future analysis of secondary organic aerosol (SOA) processing.

\section{Methods}

\subsection{Sample collection}

The data discussed in this paper was obtained from filter samples collected in Mexico City, D.F. and its environs from 17-30 March 2006. The urban site (MILAGRO site T0) was located in downtown Mexico City $\left(19.488^{\circ} \mathrm{N},-99.147\right.$, $2240 \mathrm{~m}$ a.s.l.) and was selected to characterize fresh aerosols generated in the metropolitan area. At this site, PM samplers were located on the roof of building \#20 approximately $20 \mathrm{~m}$ above ground level on the campus of Instituto Mexicano del Petróleo (IMP, Mexican Institute of Petroleum), located on the northern edge of the city. IMP is surrounded by a mixture of residential, commercial, and light industrial areas which include high motor vehicle traffic corridors. Activities surrounding this area included significant amounts of idling or slow-moving traffic, especially during morning rush hour periods.

The peripheral site (MILAGRO site T1), was selected in order to characterize a mixture of fresh and aged aerosols. The peripheral site was located on the outskirts of Mexico City, approximately $35 \mathrm{~km}$ northeast of T0 $\left(19.703^{\circ} \mathrm{N}\right.$, $-98.982,2273 \mathrm{~m}$ a.s.1.). Samplers were located at ground level on the campus of Universidad Tecnologica de Tecamac (Technological University of Tecamec). This site was located in a rural agricultural area where local primary aerosol sources were observed to include wind-blown dust and soil and motor-vehicle emissions. Compared to the urban site, vehicular traffic along adjacent roadways was light to moderate. The Mexico City basin is believed to have been influenced by emissions from forest fires in the pine-savannas in the mountains surrounding the city; other potential combustion sources included agricultural waste burning or fires in grasslands and forests, all of which were observed in southcentral Mexico during March 2006 (Yokelson et al., 2007).

Transport of aerosols from the urban to the peripheral site was highly dependant on the prevailing wind direction; for such transport to occur the dominant wind direction would have to be westerly or south-westerly. A meteorological study reported that transport was considered likely on 1822, 24-25, and 30 March and possible on other days (Fast et al., 2007). Aerosols at the peripheral site were likely influenced by local sources and by the surrounding region in addition to the variable urban influence. Precipitation events that would cause a washing-out of aerosols from the atmosphere occurred on 23-30 March 2006 (Fast et al., 2007).

Particles were collected using a medium-volume $\mathrm{PM}_{2.5}$ sampler (URG Corp., Chapel Hill, NC, USA) with a Tefloncoated aluminum cyclone inlet that selected aerosol with aerodynamic diameter less than $2.5 \mu \mathrm{m}$. Air flow through the filter was controlled by a needle valve and was measured before and after sample collection with a rotameter. The rotameter was calibrated in the laboratory over a range of inlet pressures that encompassed the ambient pressure of Mexico City. Calibration curves were used for the interpolation of the flow rate in Mexico City. Experimental results were compared to the theoretical value (Caplan, 1985) and agreed within $0.1 \%$.

Particles were collected on quartz fiber filters (QFF) (90 mm, Tissuquartz, Pall Life Sciences). Prior to sample collection QFF were baked at $550 \mathrm{C}$ for a minimum of $18 \mathrm{~h}$ to remove organic species. Before and after particle collection, QFF were stored in aluminum foil-lined Petri dishes sealed with Teflon tape. The sample date corresponded to the day that particle collection began. Daytime samples were collected from 06:00 to 18:00 CST, nighttime samples from 18:00 to 06:00, and 24-h samples began at 06:00. At the urban site, errors in labeling 12-h samples occurred from 19 March 18:00 to 21 March 18:00. The 19 March 18:00 sample was a field blank making PM data not available. The chronology of 20 and 21 March samples was reconciled by comparison to co-located chemical measurements.

\subsection{Chemical analysis}

EC and OC were measured in the laboratory using a Thermal Optical Analyzer (Sunset Laboratory, Forest Grove OR) by the ACE-Asia method (Schauer et al., 2003). Reported 
ambient concentrations of EC and OC have been field blank subtracted. The uncertainty for EC and OC measurements was calculated as the sum of the instrument uncertainty, the standard deviation of the field blanks, and five percent of the measurement. At the peripheral site, WSOC was measured using an online particle-into-liquid instrument coupled to a Total Organic Carbon analyzer (Sullivan et al., 2004).

Solvent-extractable organic species were quantified using gas chromatography mass spectrometry (GCMS) (Sheesley et al., 2004). Filters were spiked with the following isotopically-labelled internal recovery standards which were used in quantification: pyrene- $\mathrm{D}_{10}$, benz(a)anthracene- $\mathrm{D}_{12}$, coronene- $\mathrm{D}_{12}$, cholestane- $\mathrm{D}_{4}$, eicosane- $\mathrm{D}_{42}$, tetracosane$\mathrm{D}_{50}$, triacontane- $\mathrm{D}_{62}$, dotriacontane- $\mathrm{D}_{66}$, hexatriacontane$\mathrm{D}_{74}$, tetracosanoic acid-D $\mathrm{D}_{59}$, and levoglucosan- ${ }^{13} \mathrm{C}_{6}$. Filters were extracted with methanol and methylene chloride using sonication for quantification of levoglucosan and Soxhlets for all other compounds. The extracts were combined then concentrated using a rotary evaporator then a nitrogen evaporator. The extract was derivatized using diazomethane which converted carboxylic acids to methyl esters (Schauer et al., 2002). This aliquot was used for quantification of polyaromatic hydrocarbons (PAH), alkanes, hopanes, steranes, and carboxylic acids. A second derivitization was also performed using N,O-bis-(trimethylsilyl)trifluoroacetamide and 1\% Trimethylchlorosilane (Fluka, Buchs, Switzerland) which silylated hydroxyl substituents and allowed quantification of levoglucosan (Nolte et al., 2002). Reported ambient concentrations have been field blank subtracted. The uncertainty of the organic species mass concentrations was based upon the standard deviation of the field blanks, experimentally determined analytical uncertainty, and projected uncertainty associated with filter extraction.

\subsection{Source apportionment}

The contributions of primary aerosol sources to ambient OC were calculated using software available from the United States Environmental Protection Agency (EPA-CMB version 8.2). The CMB model solved for the effective-variance leastsquares solution to the linear combination of the product of the source contribution and its concentration of a set of molecular marker species observed in ambient aerosol (Watson et al., 1984). This model has been successfully used to apportion source contributions to ambient PM (Schauer et al., 2002).

The source profiles used were drawn from the most recent and comprehensive studies available at the time of this experiment. They included vegetative detritus (Rogge et al., 1993a); natural gas (Rogge et al., 1993b); motor vehicles including diesel, gasoline, and representative gasoline smoker (Lough et al., 2007), and woodsmoke. The woodsmoke profile used was a region 5 average (Sheesley et al., 2007) based on a more comprehensive study (Fine et al., 2004a). All of these profiles were reported in
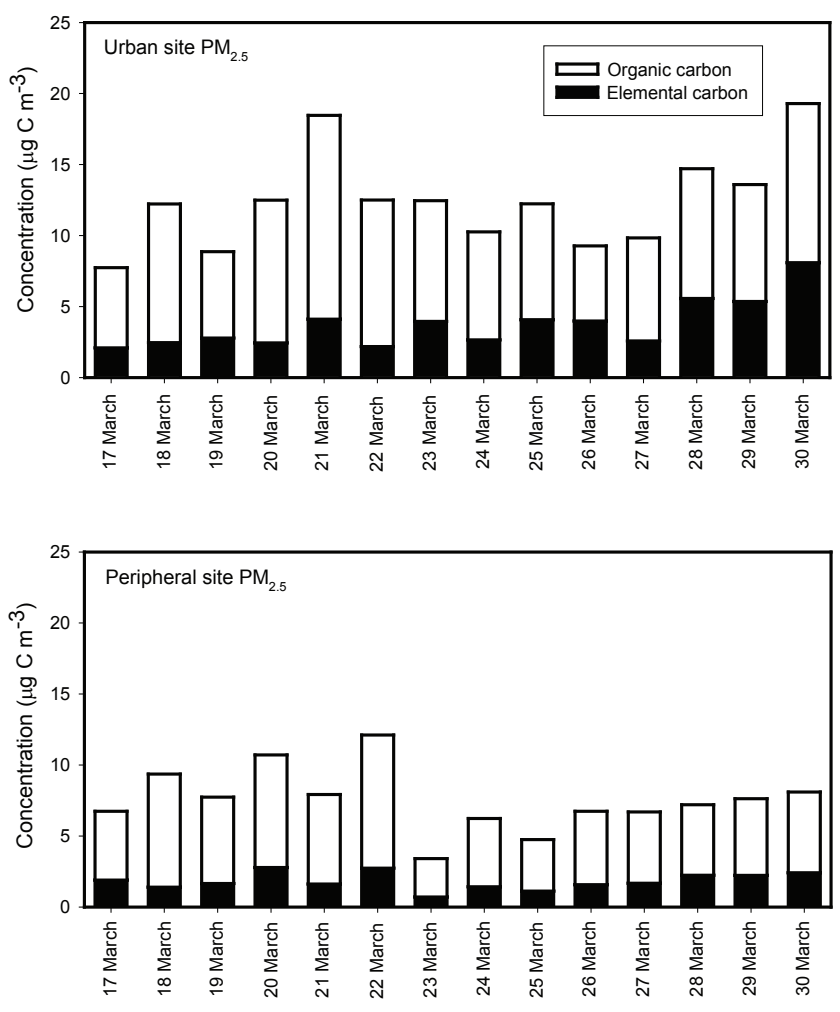

Fig. 1. Daily (24-h) EC and OC ambient mass concentrations for the urban and peripheral sites.

Sheesley et al. (2007) under the titles vegetative detritus, natural gas combustion, diesel exhaust, gasoline exhaust, gasoline non-catalyzed, and region 5 profile, respectively. The seventeen chemical species marked with a star in Table 1 were included in the model; they were: EC, a continuous series of $n$-alkanes from $\mathrm{C}_{28}-\mathrm{C}_{34}$, levoglucosan, $17 \alpha(\mathrm{H})-22,29,30$-trisnorhopane, $\quad 17 \beta(\mathrm{H})-21 \alpha(\mathrm{H})-30-$ norhopane, $17 \alpha(\mathrm{H})-21 \beta(\mathrm{H})$-hopane, benzo(b)fluoranthene, benzo(k)fluoranthene, benzo(e)pyrene, indeno(1,2,3cd)pyrene, and benzo(ghi)perylene. The series of $\mathrm{C}_{28}-\mathrm{C}_{34}$ $\mathrm{n}$-alkanes were selected because this range has been shown to demonstrate the greatest of the odd-carbon preference that is specific to biogenic sources (Rogge et al., 1993a). These particular PAH were used based upon the recommendations of previous studies (Lough et al., 2007; Sheesley et al., 2007).

\section{Results and discussion}

\subsection{EC and OC}

The 24-h average $\mathrm{PM}_{2.5} \mathrm{EC}$ and $\mathrm{OC}$ concentrations for urban and peripheral Mexico City are plotted in Fig. 1. At the urban site, OC concentrations ranged from $5.46-14.40 \mu \mathrm{g} \mathrm{C} \mathrm{m}^{-3}$ and $\mathrm{EC}$ concentrations ranged from $2.09-8.08 \mu \mathrm{g} \mathrm{C} \mathrm{m}^{-3}$ as 
Table 1. Summary of organic carbon analyses and organic species, based on a 24-h sampling time. Molecular markers used in CMB modeling are marked with a star.

\begin{tabular}{|c|c|c|c|c|c|c|c|c|}
\hline & \multicolumn{4}{|c|}{ Urban site } & \multicolumn{4}{|c|}{ Peripheral site } \\
\hline & Average & Std & Min & Max & Average & Std & Min & Max \\
\hline Organic carbon $\left(\mu \mathrm{g} \mathrm{m}^{-3}\right)^{*}$ & 8.68 & 2.43 & 5.46 & 14.40 & 5.04 & 1.56 & 2.39 & 8.28 \\
\hline Elemental carbon $\left(\mu \mathrm{g} \mathrm{m}^{-3}\right) *$ & 3.78 & 1.67 & 2.09 & 8.08 & 1.61 & 0.53 & 0.62 & 2.46 \\
\hline Water-soluble OC $\left(\mu \mathrm{g} \mathrm{m}^{-3}\right)$ & $\mathrm{nm}$ & $\mathrm{nm}$ & $\mathrm{nm}$ & $\mathrm{nm}$ & 2.88 & 0.82 & 2.04 & 5.24 \\
\hline \multicolumn{9}{|l|}{ Organic species $\left(\mathrm{ng} \mathrm{m}^{-3}\right)$} \\
\hline Levoglucosan* & 151.3 & 136.0 & 50.5 & 488.8 & 112.9 & 87.5 & 43.9 & 273.7 \\
\hline $17 \alpha(\mathrm{H})-22,29,30$-trisnorhopane* & 0.18 & 0.07 & 0.09 & 0.32 & 0.06 & 0.02 & 0.03 & 0.09 \\
\hline $17 \beta(\mathrm{H})-21 \alpha(\mathrm{H})-30$-norhopane* & 0.69 & 0.27 & 0.36 & 1.33 & 0.22 & 0.05 & 0.15 & 0.30 \\
\hline $17 \alpha(\mathrm{H})-21 \beta(\mathrm{H})$-hopane* & 0.44 & 0.16 & 0.27 & 0.83 & 0.15 & 0.04 & 0.09 & 0.23 \\
\hline 22S-homohopane & 0.23 & 0.09 & 0.12 & 0.43 & 0.07 & 0.02 & 0.04 & 0.11 \\
\hline 22R-homohopane & 0.18 & 0.09 & 0.05 & 0.35 & 0.07 & 0.02 & 0.04 & 0.11 \\
\hline$\alpha \beta \beta$-20R-C27-cholestane & 0.13 & 0.06 & 0.07 & 0.29 & 0.04 & 0.02 & $<0.02$ & 0.08 \\
\hline$\alpha \beta \beta$-20S-C27-cholestane & 0.11 & 0.07 & $<0.04$ & 0.32 & 0.04 & 0.02 & $<0.02$ & 0.07 \\
\hline$\alpha \beta \beta$-20R-C29-sitostane & 0.20 & 0.14 & 0.11 & 0.64 & 0.11 & 0.04 & 0.04 & 0.17 \\
\hline$\alpha \beta \beta$-20S-C29-sitostane & 0.18 & 0.13 & 0.05 & 0.53 & 0.10 & 0.03 & 0.04 & 0.16 \\
\hline Benzo(b)fluoranthene* & 0.47 & 0.17 & 0.29 & 0.75 & 0.39 & 0.09 & 0.24 & 0.57 \\
\hline Benzo(k)fluoranthene* & 0.40 & 0.14 & 0.25 & 0.64 & 0.26 & 0.07 & 0.15 & 0.36 \\
\hline Benzo(e)pyrene* & 0.49 & 0.17 & 0.29 & 0.83 & 0.36 & 0.11 & 0.20 & 0.54 \\
\hline Indeno(1,2,3-cd)pyrene* & 0.39 & 0.15 & 0.24 & 0.75 & 0.29 & 0.07 & 0.20 & 0.46 \\
\hline Dibenz(ah)anthracene* & 0.09 & 0.04 & 0.05 & 0.19 & 0.08 & 0.04 & $<0.04$ & 0.11 \\
\hline Benzo(ghi)perylene* & 0.91 & 0.38 & 0.48 & 1.78 & 0.45 & 0.14 & 0.23 & 0.70 \\
\hline $\mathrm{C}_{28} n$-alkane* & 4.63 & 2.31 & $<1.15$ & 9.19 & 2.00 & 0.70 & 0.95 & 3.10 \\
\hline $\mathrm{C}_{29} n$-alkane* & 6.85 & 3.04 & $<1.15$ & 12.89 & 4.28 & 2.18 & 2.00 & 7.23 \\
\hline $\mathrm{C}_{30} n$-alkane* & 3.56 & 1.21 & $<1.15$ & 5.44 & 1.79 & 0.70 & 0.89 & 3.06 \\
\hline $\mathrm{C}_{31} n$-alkane* & 5.85 & 1.94 & $<1.15$ & 8.83 & 3.77 & 2.04 & 1.89 & 8.22 \\
\hline $\mathrm{C}_{32} n$-alkane* & 2.91 & 1.06 & $<1.15$ & 4.77 & 1.51 & 0.58 & 0.78 & 2.85 \\
\hline $\mathrm{C}_{33} n$-alkane* & 3.21 & 0.82 & $<1.15$ & 4.69 & 2.28 & 1.24 & 1.05 & 3.95 \\
\hline $\mathrm{C}_{34} n$-alkane* & 2.58 & 0.57 & $<1.15$ & 3.58 & 1.29 & 0.54 & 0.73 & 2.44 \\
\hline $\mathrm{C}_{35} n$-alkane & 1.41 & 1.46 & $<1.15$ & 4.29 & 1.55 & 0.45 & 0.95 & 2.36 \\
\hline $\mathrm{C}_{36} n$-alkane & 0.91 & 1.15 & $<1.15$ & 3.21 & 1.14 & 0.26 & 0.82 & 1.63 \\
\hline pinonic acid & 6.75 & 3.02 & 3.25 & 13.62 & 4.78 & 1.32 & 2.71 & 7.16 \\
\hline
\end{tabular}

Std $=$ standard deviation

$\mathrm{nm}=$ not measured

* = marker used in CMB modeling

shown in Table 1. The average OC and EC concentrations at the urban site were $8.68 \mu \mathrm{g} \mathrm{C} \mathrm{m}^{-3}$ and $3.78 \mu \mathrm{g} \mathrm{C} \mathrm{m}^{-3}$, respectively. These values are comparable to previous studies in urban Mexico City (Chow et al., 2002; Edgerton et al., 1999; Salcedo et al., 2006) and to other megacities (Feng et al., 2006; Schauer et al., 1996). At the peripheral site, carbonaceous aerosol components were roughly half as abundant. OC concentrations ranged from 2.39$8.28 \mu \mathrm{g} \mathrm{C} \mathrm{m}^{-3}$ and EC ranged from $0.62-2.46 \mu \mathrm{g} \mathrm{C} \mathrm{m}^{-3}$. The average OC concentration was $5.04 \mu \mathrm{g} \mathrm{C} \mathrm{m}^{-3}$ while EC was $1.61 \mu \mathrm{g} \mathrm{C} \mathrm{m}^{-3}$. The decrease in carbonaceous aerosol concentrations from the urban site to the peripheral site was expected because of reduced primary sources in the outskirts of the city.

\subsection{Molecular markers}

A series of PAH, n-alkanes, and highly-specific molecular markers were measured for 24-h samples at the urban and peripheral sites. A molecular marker for organic PM is a compound that is highly specific to a single source category and is stable in the atmosphere during transport from the source to receptor within the sampling domain. 
Levoglucosan, an anhydrous carbohydrate, is a wellestablished biomarker for the combustion of biomass materials (Simoneit, 2002). The pyrolysis product of cellulose, a major component of plant material, is levoglucosan and this compound accounts for approximately $15 \%$ of primary fine particle OC resulting from biomass burning (Sheesley et al., 2007). Levoglucosan partitions to the particle-phase in the atmosphere and does not degrade (Fraser and Lakshmanan, 2000). This biomarker has been used to quantify ambient PM derived from biomass burning (Simoneit et al., 1999).

In this study, 24-h average concentrations of levoglucosan are presented in Fig. 2 for urban and peripheral sites. Levoglucosan was detected in all samples at both sites as shown in Table 1. At the urban site, levoglucosan concentrations ranged from 51-166 $\mathrm{ng} \mathrm{m}^{-3}$, except for 18 March when concentrations reached $260 \mathrm{ng} \mathrm{m}^{-3}$ and 20-21 March when concentrations reached 405 and $489 \mathrm{ng} \mathrm{m}^{-3}$, respectively. At the peripheral site, the average levoglucosan concentration was $217 \mathrm{ng} \mathrm{m}^{-3}$ from $18-22$ March and dropped to $55 \mathrm{ng} \mathrm{m}^{-3}$ from 23-30 March. This suggests that biomass burning was more consistent at the peripheral site while more episodic emissions affected the urban area.

There was no correlation between levoglucosan concentrations at the urban site and the peripheral site as shown by a linear regression analysis $\left(R^{2}=0.17\right)$. When this regression analysis was limited to days during which transport from the urban to the peripheral site was considered to be meteorologically favorable (Fast et al., 2007), correlation did not improve $\left(R^{2}=0.04\right)$. This data suggests that primary biomass combustion at the urban and peripheral sites were isolated from each other. The peripheral site, then, was likely affected by aerosols generated locally or those generated in surrounding rural areas.

Hopanes are a well-established molecular marker for fossil fuel-derived PM in the ambient atmosphere (Simoneit, 1999). Fossil fuel combustion encompasses several primary aerosol source categories: motor vehicles, coal-burning power plants, and fuel oil-burning power plants. In general, hopanes are less likely to be impacted by industrial point sources than other organic species, like PAH. Further distinction between mobile and industrial source categories is possible if additional marker species are present. Picene, for example, is specific to coal-burning (Oros and Simoneit, 2000) and can be used to infer whether or not coal-fired power plants are a major contributor to ambient OC. Fossil fuel source categories can also be distinguished from one another based on their temporal variability. It is expected that industrial point sources, like power plants, have consistent emissions from day to day and vary only on longer time scales. Emissions from motor vehicles, however, vary on much shorter time scales; diurnal (Chow et al., 2002; Marr et al., 2006; Salcedo et al., 2006) and weekly (Bae et al., 2004) emission trends have been observed in urban areas. It is expected that driving patterns differ on weekends, especially with regard to commuter traffic. In Mexico City, the "Hoy no
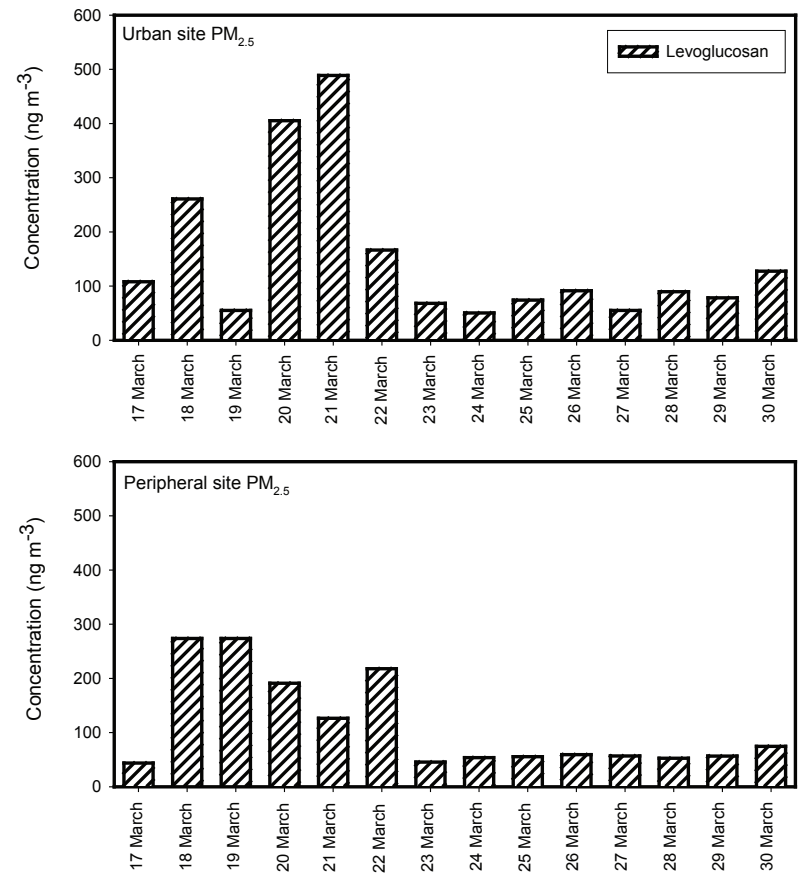

Fig. 2. Daily average levoglucosan ambient mass concentrations for the urban and peripheral sites.

circula" (HNC, "Not driving today") restrictions are enforced only on weekdays which may correlate to different types of vehicles being driven on weekends (Salcedo et al., 2006). In the absence of industrial sources, hopanes have been used to trace PM generated by both gasoline and diesel-powered motor vehicles (Schauer et al., 1999; Schauer et al., 2002).

The 24-h average concentrations for a series of three hopanes, $17 \alpha(\mathrm{H})-22,29,30$-trisnorhopane, $17 \beta(\mathrm{H})-21 \alpha(\mathrm{H})$ 30 -norhopane, and $17 \alpha(\mathrm{H})-21 \beta(\mathrm{H})$-hopane, are presented in Fig. 3 for urban and peripheral sites. Hopanes were detected in all of the 24-h average samples at both sites. The average total concentration of these three compounds at the urban site was $1.31 \mathrm{ng} \mathrm{m}^{-3}$ and was $0.44 \mathrm{ng} \mathrm{m}^{-3}$ at the peripheral site as shown in Table 1. A study of the same hopane series that took place in urban LA reported concentrations ranging from $0.8-1.4 \mathrm{ng} \mathrm{m}^{-3}$ in $\mathrm{PM}_{2.5}$ for a $3.5 \mathrm{~h}$ sampling time (Fine et al., 2004).

In this study, hopanes were considered primarily to originate from motor vehicle emissions and not other fossil-fuel source categories. A temporal trend was observed in which the average weekend concentration was lower than the average weekday concentration for the three hopanes presented in Fig. 3. Weekends were defined as Saturday, Sunday, and holidays and included 18-19, 21, and 25-26 March. The average weekday hopane concentration exceeded the average weekend concentration by $9 \%$ at the urban site and $25 \%$ at the peripheral site. This trend gives credence to 

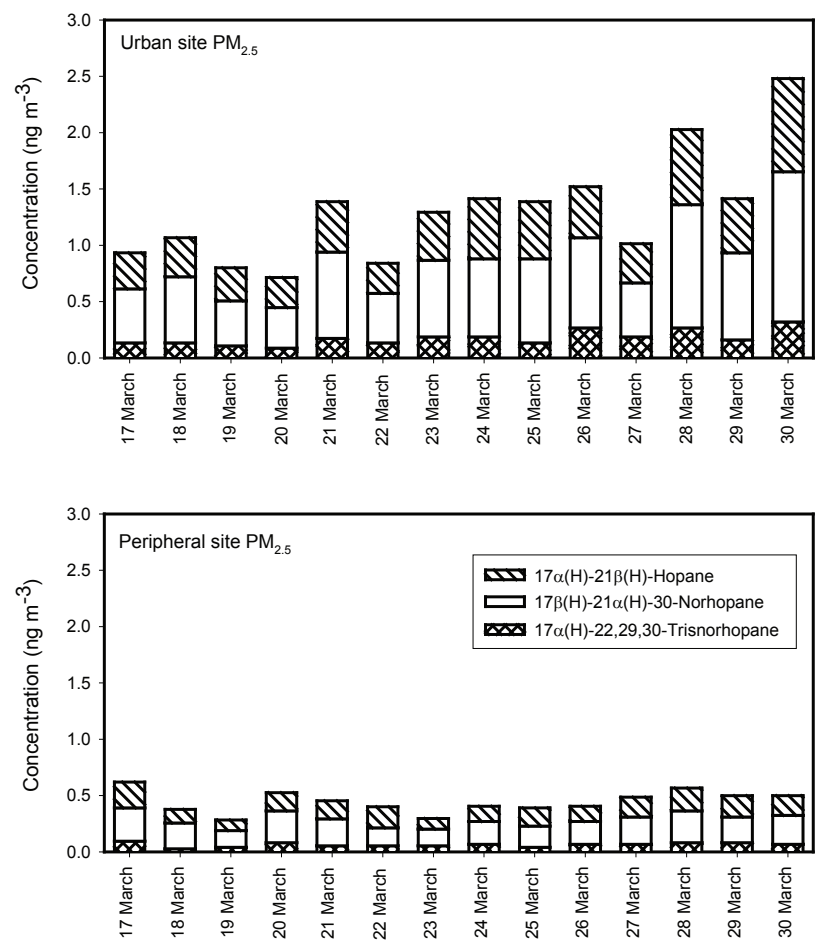

Fig. 3. Daily ambient mass concentrations for a series of hopanes at the urban and peripheral sites.

the hypothesis that motor vehicles were the major source of hopanes at the urban site in Mexico City. From the observations in this study and previous studies (Chow et al., 2002; Marr et al., 2006; Salcedo et al., 2006; Schifter et al., 2004), it is concluded that observed particle-phase hopanes predominantly resulted from motor vehicle sources.

\subsection{Source apportionment}

A molecular marker CMB analysis was used to determine the relative contribution of major sources to ambient fine organic aerosol in urban and peripheral Mexico City. Contributions of vegetative detritus, diesel engines, gasoline vehicles, smoking vehicles, woodsmoke, and non-apportioned or other sources of ambient OC for a 24-h sampling period are presented in Fig. 4 and summarized in Table 2. Natural gas combustion was considered to be a potential aerosol source, but contributed a negligible amount to OC at both urban and peripheral sties. Soil was not included as a potential source of OC in this study because a source profile specific to Mexico City and its environs was not available and $\mathrm{Si}$ and $\mathrm{Al}$ measurements were not made. If soil was a source of OC, its contribution would remain unapportioned.

Vegetative detritus accounted for approximately $0.2 \mu \mathrm{gC} \mathrm{m}^{-3}$ of $\mathrm{OC}$ at both locations in Mexico City, which corresponds to $2.3 \%$ of OC at the urban site and $3.6 \%$ of $\mathrm{OC}$ at the peripheral site. The mass contribution of
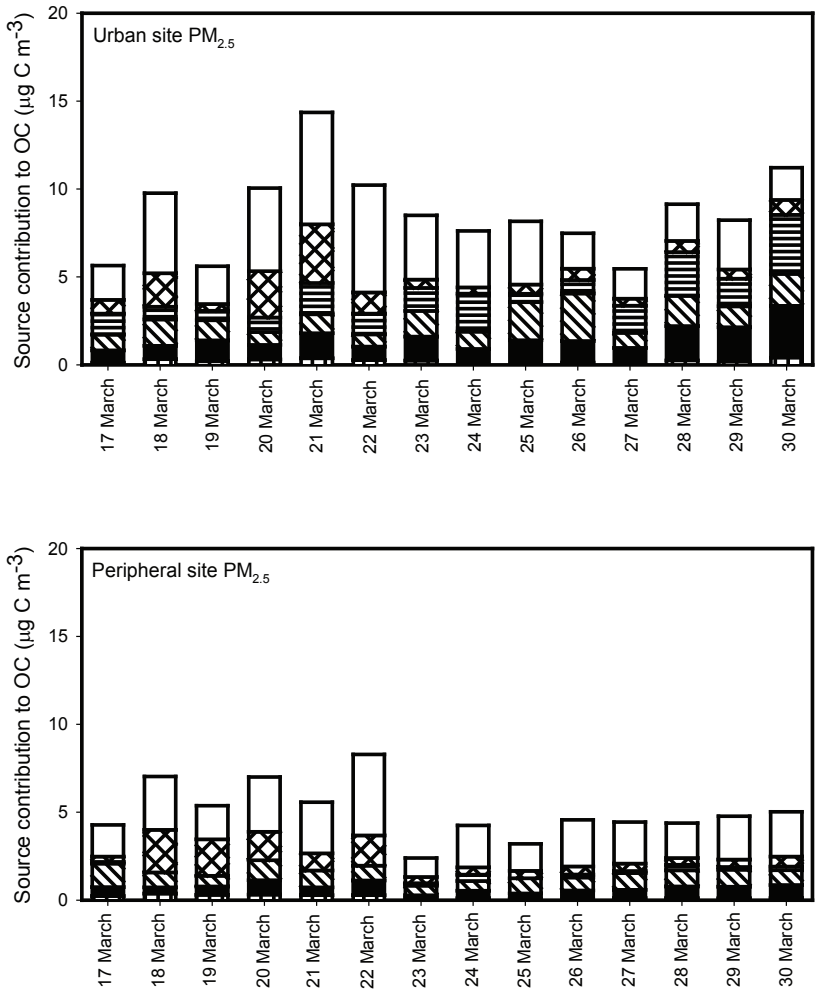

Fig. 4. Source contributions to ambient $\mathrm{OC}$ at the urban and peripheral sites determined by CMB.

vegetative detritus is comparable to that in downtown LA determined to be $0.24 \mu \mathrm{gC} \mathrm{m}^{-3}$ during a source apportionment study in 1982 (Schauer et al., 1996). The contribution of vegetative detritus to $\mathrm{OC}$ was significantly higher at the peripheral site during the beginning of the study when precipitation events did not occur $\left(0.30 \mu \mathrm{gC} \mathrm{m}^{-3}\right.$, standard deviation $0.05, n=6$ ) compared to the end of the study which was marked by rain events $\left(0.10 \mu \mathrm{gC} \mathrm{m}^{-3}\right.$, standard deviation $0.01, n=8$ ). This result suggests that the vegetative detritus contribution to $\mathrm{OC}$ changes with weather conditions.

The $\mathrm{PM}_{2.5}$ collected at the urban and peripheral sites was heavily influenced by motor vehicles. The relative contributions of diesel engines, gasoline vehicles, and smoking vehicles to OC were calculated by the CMB model based on average source profiles generated by a comprehensive study of motor vehicle emissions (Lough et al., 2007). A smoking vehicle is a high-emitting vehicle that releases visible amounts of smoke and/or produces more than $50 \mathrm{mg}$ of EC per mile (Lough et al., 2007).

On average, the sum of the contributions from diesel engines, gasoline vehicles, and smoking vehicles accounted for $49 \%$ of observed OC at the urban site. Here, diesel engines were the major source of EC and consistently accounted for $87 \%$ of the observed ambient concentration. The contribution of motor vehicles to OC decreased by approximately a 
Table 2. Source contributions in $\left(\mu \mathrm{g} \mathrm{C} \mathrm{m}^{-3}\right)$ of primary sources determined by CMB.

\begin{tabular}{|c|c|c|c|c|c|c|c|c|}
\hline & Vegetative detritus & Diesel engine & Gasoline vehicle & Smoker vehicle & Woodsmoke & Other & $R^{2}$ & $x^{2}$ \\
\hline \multicolumn{9}{|l|}{ Urban site } \\
\hline 17 March & $0.12 \pm 0.04$ & $0.70 \pm 0.11$ & $0.90 \pm 0.16$ & $1.19 \pm 0.41$ & $0.78 \pm 0.21$ & $1.95 \pm 0.93$ & 0.97 & 0.42 \\
\hline $18 \mathrm{March}$ & $0.32 \pm 0.07$ & $0.76 \pm 0.16$ & $1.50 \pm 0.35$ & $0.73 \pm 0.67$ & $1.90 \pm 0.51$ & $4.55 \pm 1.75$ & 0.85 & 1.98 \\
\hline 19 March & $0.20 \pm 0.04$ & $1.19 \pm 0.14$ & $1.15 \pm 0.18$ & $0.54 \pm 0.38$ & $0.38 \pm 0.11$ & $2.15 \pm 0.85$ & 0.91 & 2.06 \\
\hline $20 \mathrm{March}$ & $0.31 \pm 0.07$ & $0.83 \pm 0.14$ & $0.73 \pm 0.26$ & $0.83 \pm 0.54$ & $2.63 \pm 0.68$ & $4.73 \pm 1.69$ & 0.89 & 1.37 \\
\hline 21 March & $0.37 \pm 0.08$ & $1.43 \pm 0.23$ & $1.08 \pm 0.35$ & $1.78 \pm 0.78$ & $3.34 \pm 0.86$ & $6.37 \pm 2.31$ & 0.87 & 1.96 \\
\hline 22 March & $0.27 \pm 0.07$ & $0.77 \pm 0.15$ & $0.69 \pm 0.19$ & $1.18 \pm 0.53$ & $1.20 \pm 0.32$ & $6.11 \pm 1.27$ & 0.84 & 1.92 \\
\hline $23 \mathrm{March}$ & $0.24 \pm 0.06$ & $1.37 \pm 0.19$ & $1.46 \pm 0.31$ & $1.31 \pm 0.75$ & $0.47 \pm 0.13$ & $3.66 \pm 1.44$ & 0.88 & 1.86 \\
\hline 24 March & $0.00 \pm 0.05$ & $0.91 \pm 0.15$ & $0.98 \pm 0.17$ & $2.16 \pm 0.56$ & $0.36 \pm 0.10$ & $3.21 \pm 1.02$ & 0.98 & 0.37 \\
\hline 25 March & $0.05 \pm 0.04$ & $1.35 \pm 0.19$ & $2.16 \pm 0.31$ & $0.48 \pm 0.57$ & $0.52 \pm 0.15$ & $3.60 \pm 1.27$ & 0.95 & 0.76 \\
\hline 26 March & $0.13 \pm 0.04$ & $1.23 \pm 0.18$ & $2.70 \pm 0.40$ & $0.76 \pm 0.75$ & $0.64 \pm 0.18$ & $2.02 \pm 1.55$ & 0.94 & 1.06 \\
\hline 27 March & $0.06 \pm 0.04$ & $0.91 \pm 0.12$ & $0.85 \pm 0.15$ & $1.55 \pm 0.45$ & $0.40 \pm 0.11$ & $1.69 \pm 0.87$ & 0.97 & 0.52 \\
\hline $28 \mathrm{March}$ & $0.24 \pm 0.05$ & $1.96 \pm 0.25$ & $1.72 \pm 0.28$ & $2.49 \pm 0.77$ & $0.63 \pm 0.18$ & $2.09 \pm 1.52$ & 0.89 & 2.28 \\
\hline 29 March & $0.17 \pm 0.03$ & $1.96 \pm 0.24$ & $1.19 \pm 0.20$ & $1.58 \pm 0.53$ & $0.52 \pm 0.15$ & $2.81 \pm 1.16$ & 0.87 & 2.87 \\
\hline $30 \mathrm{March}$ & $0.40 \pm 0.07$ & $2.95 \pm 0.35$ & $1.82 \pm 0.31$ & $3.35 \pm 0.91$ & $0.85 \pm 0.24$ & $1.83 \pm 1.88$ & 0.82 & 4.66 \\
\hline \multicolumn{9}{|l|}{ Peripheral site } \\
\hline 17 March & $0.24 \pm 0.04$ & $0.51 \pm 0.09$ & $1.34 \pm 0.19$ & $0.09 \pm 0.33$ & $0.31 \pm 0.09$ & $1.80 \pm 0.74$ & 0.78 & 4.73 \\
\hline $18 \mathrm{March}$ & $0.38 \pm 0.06$ & $0.35 \pm 0.09$ & $0.85 \pm 0.13$ & BD & $2.42 \pm 0.49$ & $3.03 \pm 0.77$ & 0.77 & 3.84 \\
\hline 19 March & $0.30 \pm 0.05$ & $0.48 \pm 0.08$ & $0.61 \pm 0.10$ & $\mathrm{BD}$ & $2.08 \pm 0.42$ & $1.91 \pm 0.65$ & 0.82 & 3.02 \\
\hline $20 \mathrm{March}$ & $0.32 \pm 0.05$ & $0.82 \pm 0.13$ & $1.13 \pm 0.15$ & $\mathrm{BD}$ & $1.61 \pm 0.38$ & $3.12 \pm 0.70$ & 0.78 & 4.13 \\
\hline 21 March & $0.29 \pm 0.06$ & $0.44 \pm 0.10$ & $0.96 \pm 0.15$ & $\mathrm{BD}$ & $0.98 \pm 0.25$ & $2.90 \pm 0.56$ & 0.81 & 2.08 \\
\hline 22 March & $0.28 \pm 0.06$ & $0.83 \pm 0.14$ & $0.84 \pm 0.15$ & BD & $1.72 \pm 0.42$ & $4.61 \pm 0.76$ & 0.84 & 1.92 \\
\hline 23 March & $0.10 \pm 0.02$ & $0.18 \pm 0.04$ & $0.54 \pm 0.09$ & $0.14 \pm 0.17$ & $0.36 \pm 0.09$ & $1.07 \pm 0.42$ & 0.78 & 4.02 \\
\hline 24 March & $0.10 \pm 0.02$ & $0.43 \pm 0.08$ & $0.55 \pm 0.10$ & $0.36 \pm 0.20$ & $0.42 \pm 0.11$ & $2.38 \pm 0.50$ & 0.80 & 4.07 \\
\hline 25 March & $0.09 \pm 0.02$ & $0.29 \pm 0.06$ & $0.87 \pm 0.10$ & BD & $0.42 \pm 0.11$ & $1.53 \pm 0.29$ & 0.83 & 2.63 \\
\hline $26 \mathrm{March}$ & $0.08 \pm 0.02$ & $0.46 \pm 0.08$ & $0.74 \pm 0.12$ & $0.17 \pm 0.22$ & $0.46 \pm 0.12$ & $2.65 \pm 0.56$ & 0.81 & 3.65 \\
\hline 27 March & $0.11 \pm 0.02$ & $0.47 \pm 0.09$ & $0.95 \pm 0.15$ & $0.12 \pm 0.26$ & $0.42 \pm 0.11$ & $2.36 \pm 0.62$ & 0.80 & 4.12 \\
\hline $28 \mathrm{March}$ & $0.11 \pm 0.02$ & $0.67 \pm 0.10$ & $0.92 \pm 0.14$ & $0.32 \pm 0.27$ & $0.39 \pm 0.10$ & $1.99 \pm 0.64$ & 0.80 & 4.40 \\
\hline 29 March & $0.10 \pm 0.02$ & $0.67 \pm 0.10$ & $0.97 \pm 0.15$ & $0.15 \pm 0.27$ & $0.42 \pm 0.11$ & $2.47 \pm 0.65$ & 0.81 & 4.04 \\
\hline 30 March & $0.11 \pm 0.02$ & $0.75 \pm 0.11$ & $0.84 \pm 0.14$ & $0.21 \pm 0.25$ & $0.57 \pm 0.15$ & $2.55 \pm 0.66$ & 0.80 & 4.56 \\
\hline \multicolumn{9}{|l|}{$\begin{array}{l}\text { Urban site } \\
\text { (12-h average) }\end{array}$} \\
\hline 18 March 06:00 & $0.24 \pm 0.04$ & $0.60 \pm 0.11$ & $1.22 \pm 0.18$ & $0.03 \pm 0.35$ & $\mathrm{~nm}$ & $5.08 \pm 0.87$ & 0.81 & 3.15 \\
\hline 18 March 18:00 & $0.45 \pm 0.07$ & $0.89 \pm 0.19$ & $2.76 \pm 0.39$ & $0.50 \pm 0.69$ & $\mathrm{~nm}$ & $5.86, \pm 1.61$ & 0.75 & 5.16 \\
\hline 19 March 06:00 & $0.20 \pm 0.04$ & $1.18 \pm 0.14$ & $1.24 \pm 0.18$ & $0.44 \pm 0.39$ & $\mathrm{~nm}$ & $2.00 \pm 0.90$ & 0.90 & 2.10 \\
\hline 20 March 06:00 & $0.41 \pm 0.07$ & $1.12 \pm 0.19$ & $1.68 \pm 0.25$ & $0.45 \pm 0.52$ & $\mathrm{~nm}$ & $4.23 \pm 0.75$ & 0.83 & 3.06 \\
\hline 20 March 18:00 & $0.25 \pm 0.04$ & $0.52 \pm 0.09$ & $0.92 \pm 0.11$ & BD & $\mathrm{nm}$ & $6.15 \pm 1.94$ & 0.82 & 2.71 \\
\hline 21 March 06:00 & $0.33 \pm 0.05$ & $1.17 \pm 0.20$ & $1.43 \pm 0.21$ & $1.18 \pm 0.51$ & $\mathrm{~nm}$ & $6.78 \pm 2.40$ & 0.80 & 3.98 \\
\hline 21 March 18:00 & $0.46 \pm 0.08$ & $1.67 \pm 0.26$ & $2.27 \pm 0.33$ & $0.77 \pm 0.68$ & $\mathrm{~nm}$ & $6.90 \pm 1.23$ & 0.78 & 4.54 \\
\hline 22 March 06:00 & $0.13 \pm 0.03$ & $0.71 \pm 0.14$ & $0.63 \pm 0.10$ & $0.26 \pm 0.25$ & $\mathrm{~nm}$ & $7.21 \pm 0.67$ & 0.87 & 1.64 \\
\hline 22 March 18:00 & $0.38 \pm 0.07$ & $0.83 \pm 0.17$ & $1.31 \pm 0.20$ & $1.55 \pm 0.53$ & $\mathrm{~nm}$ & $6.19 \pm 1.15$ & 0.81 & 3.33 \\
\hline 23 March 06:00 & $0.27 \pm 0.06$ & $1.98 \pm 0.25$ & $2.25 \pm 0.33$ & $1.75 \pm 0.76$ & $\mathrm{~nm}$ & $2.73 \pm 1.54$ & 0.87 & 2.72 \\
\hline 23 March 18:00 & $0.16 \pm 0.05$ & $0.76 \pm 0.13$ & $0.90 \pm 0.14$ & $0.69 \pm 0.34$ & $\mathrm{~nm}$ & $4.59 \pm 0.77$ & 0.84 & 2.46 \\
\hline
\end{tabular}

$\mathrm{BD}=$ below detection

$\mathrm{nm}=$ not measured

factor of three at the peripheral site relative to the downtown site. This reduction in the absolute contribution of motor vehicles to $\mathrm{OC}$ at the periphery is expected because motor vehicle traffic is lighter. Here, motor vehicles accounted for $32 \%$ of OC on average and diesel engines produced $80 \%$ of EC.
Gasoline vehicles exhibited a weekly trend in the downtown area. Properly functioning (non-smoking) vehicles accounted for $41 \%$ (standard deviation $7 \%$ ) of gasolinepowered motor vehicle OC on weekdays and $74 \%$ (standard deviation $8 \%$ ) on weekends, whereas smoking vehicles accounted for the rest. The OC attributed to gasolinepowered motor vehicles on 21 March, a holiday, was similar 
to weekdays. This result suggests that different types of cars were driven on weekends and weekdays. A similar trend was observed on the periphery of the city, but was less pronounced. This implies that the peripheral site is influenced by local motor vehicle traffic and that weekly vehicular patterns are similar in the downtown area and at the perimeter of the city.

Woodsmoke was an important primary source of OC in downtown Mexico City, second only to motor vehicles. In the urban area, woodsmoke accounted for $5-26 \%$ of observed OC on a daily basis and its mass contribution ranged from $0.36-3.34 \mu \mathrm{gC} \mathrm{m}^{-3}$ as shown in Table 2. The contribution of woodsmoke to $\mathrm{OC}$ on the periphery of Mexico City ranged from $7-39 \%$ and its mass contribution ranged from $0.31-2.42 \mu \mathrm{gC} \mathrm{m}^{-3}$. These results are comparable to a source apportionment study that occurred in downtown LA during 1982, where the average annual contribution of woodsmoke to fine particle OC was determined to be $1.85 \pm 0.31 \mu \mathrm{g} \mathrm{m}^{-3}$ (Schauer et al., 1996).

At the urban site, woodsmoke contributions to ambient OC were pronounced on 18 and 20-21 March compared to other days. The irregular occurrence of wood burning as a major source of OC indicates that it was a point source that sporadically affected the urban site. The woodsmoke contribution to $\mathrm{OC}$ at the peripheral site was not as temporally irregular. Rather, the woodsmoke contributions were highest from 18-22 March when the average contribution was $1.76 \mu \mathrm{gC} \mathrm{m}^{-3}$ compared to the remainder of the study when the average contribution was $0.42 \mu \mathrm{gC} \mathrm{m}^{-3}$. This temporal trend is analogous to vegetative detritus. Elevated amounts of woodsmoke aerosol at the downtown site did not correspond to elevated woodsmoke aerosol at the perimeter of the city. This was particularly noticeable on 21 March when woodsmoke contributions reached $3.34 \mu \mathrm{gC} \mathrm{m}^{-3}$ at the urban site while woodsmoke contributions fell below average for the period of no precipitation at the peripheral site. This temporal discrepancy suggests that the woodsmoke events that affected the urban area did not affect the periphery.

At the peripheral site, woodsmoke contributions to OC were highly correlated with vegetative detritus contributions $\left(R^{2}=0.77\right)$. At this site, woodsmoke and vegetative detritus likely comprised a single source: biomass burning. Open burning of biomass material generates aerosols containing carbonaceous plant material or vegetative detritus that are suspended into the atmosphere by thermally-driven convection. It is likely that this type of process is responsible for the woodsmoke aerosol on the perimeter of the city. The woodsmoke contribution at the urban site has a much weaker correlation with vegetative detritus $\left(R^{2}=0.42\right)$, either because of additional sources of vegetative detritus at the urban site or the different nature of biomass burning within the urban area. It has been suggested cottage industries, such as adobe brick-making and tile-making, are primary sources of biomass burning in the urban area (Raga et al., 2001). These types of wood-burning processes are not expected to suspend significant amounts of vegetative detritus like an open biomass burn would. The results of this study suggest that the aerosol generated by biomass burning on the perimeter of the city is chemically different from the point-source wood-burning events that pollute the downtown area.

Other sources of aerosol, which were not included in the $\mathrm{CMB}$ model, contributed to a major portion of OC at both the urban and peripheral sites. OC unapportioned to primary sources accounted for 16-60\% of ambient OC at the urban site and $36-58 \%$ at the peripheral site as shown in Table 2. The source of the unapportioned OC could include unknown or uncharacterized primary sources such as soil. In a study where the primary sources of OC were limited, the unapportioned OC was attributed to secondary sources (Sheesley et al., 2004). Secondary transformation of gas-phase volatile or semi-volatile organic species may occur by photochemical oxidation. The addition of oxygen to carbonaceous compounds decreases volatility and increases partitioning to the condensed, or aerosol, phase. Oxidation products are expected to be more water-soluble than their precursors because of increased polarity and potential for hydrogen-bonding. The mass contribution of secondary sources to OC would be expected to correlate with the mass concentration of WSOC. It is notable that fine particle WSOC is also produced by biomass burning; $71 \%$ of organic aerosol in a biomass event has been found to be water-soluble (Sannigrahi et al., 2006).

In this study, ambient fine particle WSOC concentrations were measured only at the peripheral site. The biomass contribution to OC was estimated to be $71 \%$ water-soluble (Sannigrahi et al., 2006). The sum of the unapportioned OC and the biomass contribution to WSOC are compared to ambient WSOC measurements in Fig. 5. A positive correlation is observed $\left(R^{2}=0.77\right)$. The slope of unity was expected and the experimental results deviate by $9 \%$. The robustness of the correlation, furthermore, suggested that the unapportioned $\mathrm{OC}$ is water-soluble. This result precludes soil from being an important primary source because the $\mathrm{OC}$ in soil is primarily hydrophobic since hydrophilic compounds would be washed out by precipitation. Secondary sources are considered to be the major uncharacterized source of $\mathrm{OC}$ at the urban and peripheral sites. Finally, this correlation provides support that the CMB modeling results are reasonable.

\subsection{Daytime vs. nighttime}

EC and OC concentrations in the urban site averaged over a 12-h period for 18-24 March 2006 are shown in Fig. 6. The daytime samples correspond to daylight hours and were collected from 06:00 to 18:00 local time and vice versa for nighttime samples. There is no pattern of EC and OC at night compared to daytime. This result indicates that $\mathrm{EC}$ and OC concentrations were more strongly influenced by primary sources and meteorology than time of day. 


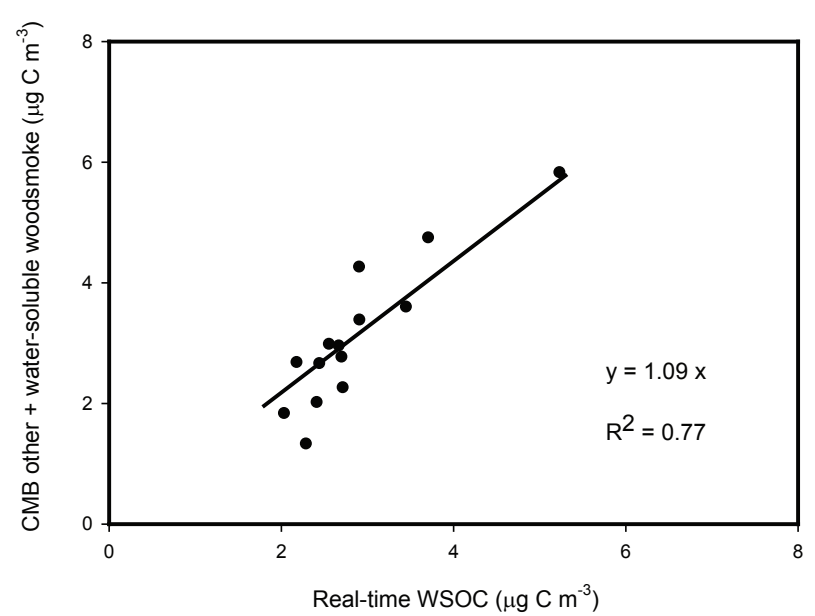

Fig. 5. A comparison of ambient real-time WSOC concentrations to the sum of the CMB other contribution to $\mathrm{OC}$ and the water-soluble fraction of woodsmoke measured at the peripheral site.

The contributions to daytime and nighttime OC from vegetative detritus and motor vehicles are presented in Fig. 6. Levoglucosan measurements were not available and woodsmoke was not apportioned, however due to the sporadic nature of woodsmoke emissions it is not expected that they differ with respect to time of day. There are no statistically significant differences between sources of OC during the nighttime and daytime, as shown in Table 2. However, there is an average reduction in the diesel engine contribution to $\mathrm{OC}$ by $21 \%$ during the nighttime, suggesting that diesel traffic is heavier during the daytime. Additionally, the contribution of vegetative detritus to OC is $30 \%$ greater at night compared to daytime.

The chemical composition of the aerosol was not statistically different between day and night, but showed variability in relation to primary sources. Pinonic acid, for example, is an expected secondary organic species that has been formed in chamber studies by the photochemical oxidation of $\alpha$-pinene (Yu et al., 1999). This compound is expected to form only during daylight hours. However, a previous study reported elevated pinonic acid concentrations at night relative to daytime and attributed this result to the semi-volatile nature of this compound and enhanced partitioning to the particle phase at lower temperatures (Cahill et al., 2006). Pinonic acid was observed in every 12 -h sample collected at the urban site in Mexico City. The 12-h daytime average was not statistically significant from the nighttime average. The 12-h daytime pinonic acid concentration ranged from 2.4$7.5 \mathrm{ng} \mathrm{m}^{-3}$ and the nighttime concentration ranged from 4.6$25.8 \mathrm{ng} \mathrm{m}^{-3}$. The maximum 12-h average nighttime concentration occurred on 21 March and the maximum daytime concentration occurred on the following day. The time period of elevated pinonic acid corresponded to maximum OC contributions from secondary sources and immediately followed
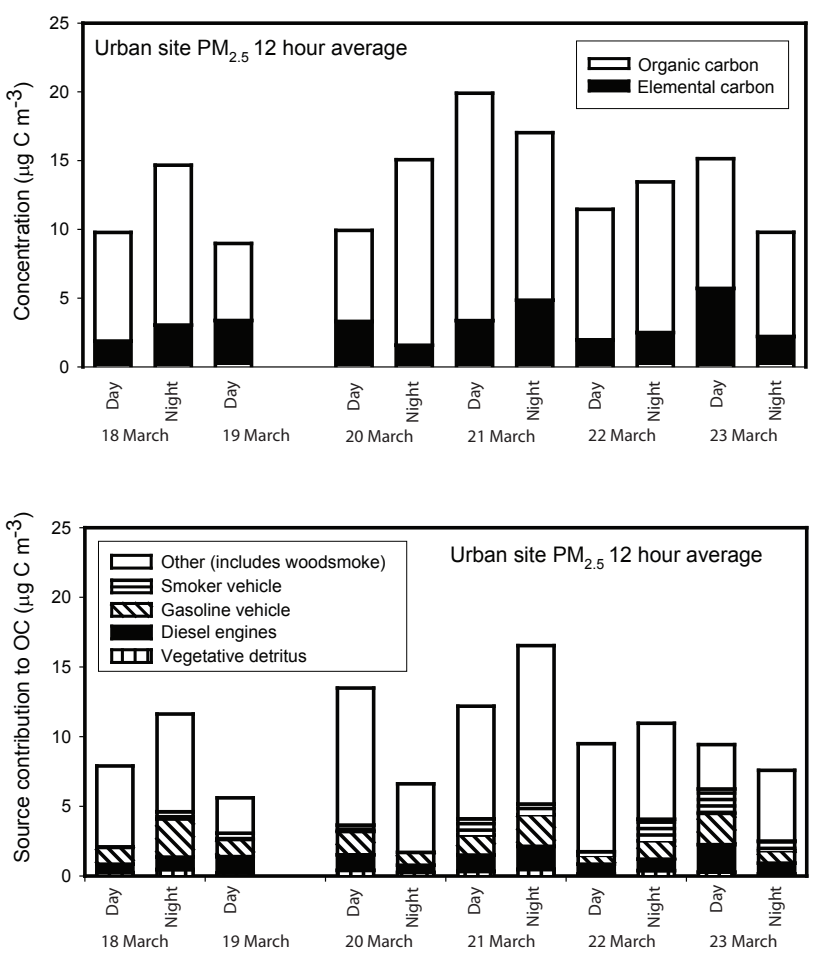

Fig. 6. EC and OC ambient mass concentrations and source contributions to OC for select 12-h samples at the urban site. (Data for the night of 19 March is not available.)

the period of elevated woodsmoke. This result suggests that pinonic acid is formed in the atmosphere and is associated with woodsmoke events. It also supports the conclusion of this study that secondary sources contributed to ambient OC at the urban and peripheral sites.

\section{Conclusions}

Ambient aerosol collected at urban and peripheral sites in Mexico City were heavily impacted by primary emissions from motor vehicles and biomass combustion in addition to secondary aerosol formed in the atmosphere. Motor vehicles contributed on average $49 \%$ of ambient OC at the urban site and $32 \%$ at the peripheral site. The daily contribution of motor vehicles to $\mathrm{PM}_{2.5}$ was fairly consistent over the course of the study but varied between weekdays and weekends. Woodsmoke episodes occurred sporadically at the urban site and accounted for 5-30\% of ambient OC, whereas biomass burning more regularly affected the perimeter of the city and accounted for 7-39\% of OC. Mutually inconsistent temporal patterns and chemical signatures of woodsmoke indicate that the peripheral site was influenced by local aerosol sources rather than urban outflow. The unapportioned OC plus the water-soluble fraction of woodsmoke correlated well with WSOC which implicated SOA as an important component of 
both urban and peripheral OC. Comparison of 12-h samples collected in daylight to those collected at night revealed that primary source contributions were not strongly dependant on time of day. This study provides a quantitative understanding and analysis of important sources to OC collected at urban and peripheral sites in Mexico City during the MILAGRO field campaign from 17-30 March 2006.

Acknowledgements. This research was funded by the National Science Foundation (NSF). We thank R. G. Abraham, G. Sosa, and A. Rutter for technical support at the urban site and L. Padro for sample collection at the peripheral site. We also thank J. DeMinter and B. Shelton at the Wisconsin State Laboratory of Hygiene and J. Zhou from Wuhan University in China for filter preparation and analysis.

Edited by: L. Molina

\section{References}

Bae, M. S., Schauer, J. J., DeMinter, J. T., and Turner, J. R.: Hourly and daily patterns of particle-phase organic and elemental carbon concentrations in the urban atmosphere, J. Air Waste Manage., 54(7), 823-833, 2004.

Cahill, T. M., Seaman, V. Y., Charles, M. J., Holzinger, R., and Goldstein, A. H.: Secondary organic aerosols formed from oxidation of biogenic volatile organic compounds in the Sierra Nevada Mountains of California, J. Geophys. Res.-Atmos., 111(D16), D16312, doi:10.1029/2006JD007178, 2006.

Caplan, K. J.: Rotameter Corrections For Gas-Density, Am. Ind. Hyg. Assoc. J., 46(11), B10-16, 1985.

Chow, J. C., Watson, J. G., Edgerton, S. A., Vega, E., and Ortiz, E.: Spatial differences in outdoor PM10 mass and aerosol composition in Mexico City, J. Air Waste Manage., 52(4), 423-434, 2002.

Dockery, D. W., Schwartz, J., and Spengler, J. D.: Air-Pollution And Daily Mortality - Associations With Particulates And Acid Aerosols, Environ. Res., 59(2), 362-373, 1992.

Edgerton, S. A., Bian, X., Doran, J. C., Fast, J. D., Hubbe, J. M., Malone, E. L., Shaw, W. J., Whiteman, C. D., Zhong, S., Arriaga, J. L., Ortiz, E., Ruiz, M., Sosa, G., Vega, E., Limon, T., Guzman, F., Archuleta, J., Bossert, J. E., Elliot, S. M., Lee, J. T., McNair, L. A., Chow, J. C., Watson, J. G., Coulter, R. L., Doskey, P. V., Gaffney, J. S., Marley, N. A., Neff, W., and Petty, R.: Particulate air pollution in Mexico City: A collaborative research project, J. Air Waste Manage., 49(10), 1221-1229, 1999.

Fast, J. D., De Foy, B., Acevedo Rosas, F., Caetano, E., Carmichael, G., Emmons, L., McKenna, D., Mena, M., Skamarock, W., Tie, X., Coulter, R. L., Barnard, J. C., Wiedinmyer, C., and Madronich, S.: A meteorological overview of the MILAGRO field campaigns, Atmos. Chem. Phys., 7, 2233-2257, 2007, http://www.atmos-chem-phys.net/7/2233/2007/.

Feng, J. L., Hu, M., Chan, C. K., Lau, P. S., Fang, M., He, L. Y., and Tang, X. Y.: A comparative study of the organic matter in PM2.5 from three Chinese megacities in three different climatic zones, Atmos. Environ., 40(21), 3983-3994, 2006.

Fine, P. M., Chakrabarti, B., Krudysz, M., Schauer, J. J., and Sioutas, C.: Diurnal variations of individual organic compound constituents of ultrafine and accumulation mode particulate matter in the Los Angeles basin, Environ. Sci. Technol., 38(5), 12961304, 2004.

Fraser, M. P. and Lakshmanan, K.: Using levoglucosan as a molecular marker for the long-range transport of biomass combustion aerosols, Environ. Sci. Technol., 34(21), 4560-4564, 2000.

Johnson, K. S., de Foy, B., Zuberi, B., Molina, L. T., Molina, M. J., Xie, Y., Laskin, A., and Shutthanandan, V.: Aerosol composition and source apportionment in the Mexico City Metropolitan Area with PIXE/PESA/STIM and multivariate analysis, Atmos. Chem. Phys., 6, 4591-4600, 2006,

http://www.atmos-chem-phys.net/6/4591/2006/.

Lough, G. C., Christenson, C. C., Schauer, J. J., Tortorelli, J., Bean, E., Lawson, D., Clark, N. N., and Gabele, P. A.: Development of Molecular Marker Source Profiles for Emissions from OnRoad Gasoline and Diesel Vehicle Fleets, J. Air Waste Manage., 57(10), 1190-1199, 2007.

Marr, L. C., Dzepina, K., Jimenez, J. L., Reisen, F., Bethel, H. L., Arey, J., Gaffney, J. S., Marley, N. A., Molina, L. T., and Molina, M. J.,: Sources and transformations of particle-bound polycyclic aromatic hydrocarbons in Mexico City, Atmos. Chem. Phys., 6, 1733-1745, 2006, http://www.atmos-chem-phys.net/6/1733/2006/.

Molina, L. T. and Molina, M. J.: Improving air quality in megacities - Mexico City Case Study, Ann. NY. Acad. Sci., p. 1023, 142158, 2004.

National Center for Atmospheric Research, Earth Observing Laboratory (NCAR/EOL): MILAGRO, available at: www.eol.ucar. edu/projects/milagro, last access: October 2007, 2006.

Nolte, C. G., Schauer, J. J., Cass, G. R., and Simoneit, B. R. T.: Trimethylsilyl derivatives of organic compounds in source samples and in atmospheric fine particulate matter, Environ. Sci. Technol., 36(20), 4273-4281, 2002.

Oros, D. R. and Simoneit, B. R. T.: Identification and emission rates of molecular tracers in coal smoke particulate matter, Fuel, 79(5), 515-536, 2000.

Raga, G. B., Baumgardner, D., Castro, T., Martinez-Arroyo, A., and Navarro-Gonzalez, R.: Mexico City air quality: a qualitative review of gas and aerosol measurements (1960-2000), Atmos. Environ., 35(23), 4041-4058, 2001.

Rogge, W. F., Hildemann, L. M., Mazurek, M. A., Cass, G. R., and Simoneit, B. R. T.: Sources Of Fine Organic Aerosol, 4. Particulate Abrasion Products From Leaf Surfaces Of Urban Plants, Environ. Sci. Technol., 27(13), 2700-2711, 1993a.

Rogge, W. F., Hildemann, L. M., Mazurek, M. A., Cass, G. R., and Simoneit, B. R. T.: Sources Of Fine Organic Aerosol, 5. Natural-Gas Home Appliances, Environ. Sci. Technol., 27(13), 2736-2744, 1993b.

Salcedo, D., Onasch, T. B., Dzepina, K., Canagaratna, M. R., Zhang, Q., Huffman, J. A., DeCarlo, P. F., Jayne, J. T., Mortimer, P., Worsnop, D. R., Kolb, C. E., Johnson, K. S., Zuberi, B., Marr, L. C., Volkamer, R., Molina, L. T., Molina, M. J., Cardenas, B., Bernabe, R. M., Marquez, C., Gaffney, J. S., Marley, N. A., Laskin, A., Shutthanandan, V., Xie, Y., Brune, W., Lesher, R., Shirley, T., and Jimenez, J. L.: Characterization of ambient aerosols in Mexico City during the MCMA-2003 campaign with Aerosol Mass Spectrometry: results from the CENICA Supersite, Atmos. Chem. Phys., 6, 925-946, 2006, http://www.atmos-chem-phys.net/6/925/2006/. 
Saldiva, P. H. N., Pope, C. A., Schwartz, J., Dockery, D. W., Lichtenfels, A. J., Salge, J. M., Barone, I., and Bohm, G. M.: Air-Pollution And Mortality In Elderly People - A Time-Series Study In Sao-Paulo, Brazil, Arch. Environ. Health., 50(2), 159163, 1995.

Sannigrahi, P., Sullivan, A. P., Weber, R. J., and Ingall, E. D.: Characterization of water-soluble organic carbon in urban atmospheric aerosols using solid-state C-13 NMR spectroscopy, Environ. Sci. Technol., 40(3), 666-672, 2006.

Schauer, J. J., Kleeman, M. J., Cass, G. R., and Simoneit, B. R. T.: Measurement of emissions from air pollution sources, 2. C1 through C-30 organic compounds from medium duty diesel trucks, Environ. Sci. Technol., 33(10), 1578-1587, 1999.

Schauer, J. J., Kleeman, M. J., Cass, G. R., and Simoneit, B. R. T.: Measurement of emissions from air pollution sources, 5. C-1-C32 organic compounds from gasoline-powered motor vehicles, Environ. Sci. Technol., 36(6), 1169-1180, 2002.

Schauer, J. J., Mader, B. T., Deminter, J. T., Heidemann, G., Bae, M. S., Seinfeld, J. H., Flagan, R. C., Cary, R. A., Smith, D., Huebert, B. J., Bertram, T., Howell, S., Kline, J.T., Quinn, P., Bates, T., Turpin, B., Lim, H. J., Yu, J. Z., Yang, H., and Keywood, M. D.: ACE-Asia intercomparison of a thermal-optical method for the determination of particle-phase organic and elemental carbon, Environ. Sci. Technol., 37(5), 993-1001, 2003.

Schauer, J. J., Rogge, W. F., Hildemann, L. M., Mazurek, M. A., and Cass, G. R.: Source apportionment of airborne particulate matter using organic compounds as tracers, Atmos. Environ., 30(22), 3837-3855, 1996.

Schifter, I., Diaz, L., Avalos, S., Vera, N., Mejia, I., Reyes, F., and Lopez-Salinas, E.: Trends of exhaust emissions from gasoline motor vehicles in the metropolitan area of Mexico city, Int. J. Environ. Pollut., 21(2), 166-174, 2004.

Schwartz, J. and Marcus, A.: Mortality And Air-Pollution In London - A Time-Series Analysis, Am. J. Epidemiol., 131(1), 185194, 1990.

Sheesley, R. J., Schauer, J. J., Bean, E., and Kenski, D.: Trends in secondary organic aerosol at a remote site in Michigan's upper peninsula, Environ. Sci. Technol., 38(24), 6491-6500, 2004.
Sheesley, R. J., Schauer, J. J., Zheng, M., and Wang, B.: Sensitivity of molecular marker-based CMB models to biomass burning source profiles, Atmos. Environ., 41, 9050-9063, 2007.

Simoneit, B. R. T.,: A review of biomarker compounds as source indicators and tracers for air pollution, Environ. Sci. Pollut. R., 6(3), 159-169, 1999.

Simoneit, B. R. T.: Biomass burning - A review of organic tracers for smoke from incomplete combustion, Appl. Geochem., 17(3), 129-162, 2002.

Simoneit, B. R. T., Schauer, J. J., Nolte, C. G., Oros, D. R., Elias, V. O., Fraser, M. P., Rogge, W. F., and Cass, G. R.: Levoglucosan, a tracer for cellulose in biomass burning and atmospheric particles, Atmos. Environ., 33(2), 173-182, 1999.

Sullivan, A. P., Weber, R. J., Clements, A. L., Turner, J. R., Bae, M. S., and Schauer, J. J.: A method for on-line measurement of water-soluble organic carbon in ambient aerosol particles: Results from an urban site, Geophys. Res. Lett., 31(13), L13105, doi:10.1029/2004GL019681, 2004.

Sun, J. M. and Ariya, P. A.: Atmospheric organic and bio-aerosols as cloud condensation nuclei $(\mathrm{CCN})$ : A review, Atmos. Environ., 40(5), 795-820, 2006.

Watson, J. G., Cooper, J. A., and Huntzicker, J. J.: The Effective Variance Weighting For Least-Squares Calculations Applied To The Mass Balance Receptor Model, Atmos. Environ., 18(7), 1347-1355, 1984.

Yokelson, R., Urbanski, S., Atlas, E., Toohey, D., Alvarado, E., Crounse, J., Wennberg, P., Fisher, M., Wold, C., Campos, T., Adachi, K., Busek, P. R., and Hao, W. M.: Emissions from forest fires near Mexico City, Atmos. Chem. Phys. Discuss., 7, 66876718, 2007, http://www.atmos-chem-phys-discuss.net/7/6687/2007/.

Yu, J. Z., Cocker, D. R., Griffin, R. J., Flagan, R. C., and Seinfeld, J. H.: Gas-phase ozone oxidation of monoterpenes: Gaseous and particulate products, J. Atmos. Chem., 34(2), 207-258, 1999. 